\title{
Factors Affecting Tourist Satisfaction: A Study in Sylhet Region
}

\author{
Debashish Roy ${ }^{1}$ \\ Md. Gulam Mokta Dhir ${ }^{2}$ \\ Mohammad Kamrul Ahsan ${ }^{3}$ \\ ${ }^{1,3}$ Assistant Professor, Department of Business Administration, Metropolitan University, Sylhet, Bangladesh \\ ${ }^{2}$ Senior Lecturer, Department of Business Administration, Metropolitan University, Sylhet, Bangladesh \\ ${ }^{1}$ (debashish@metrouni.edu.bd) \\ ${ }^{2}$ (muktadhir@metroui.edu.bd) \\ 3(ahsan404243@gmail.com) \\ Received 23 February, 2017
}

This journal is licensed under a Creative Commons Attribution-NonCommercial 4.0 International License (CC-BY-NC). Articles can be read and shared for noncommercial purposes under the following conditions:

- BY: Attribution must be given to the original source (Attribution)

- NC: Works may not be used for commercial purposes (Noncommercial)

This license lets others remix, tweak, and build upon your work non-commercially, and although their new works must also acknowledge you and be non-commercial, they don't have to license their derivative works on the same terms. License Deed Link: http://creativecommons.org/licenses/by-nc/4.0/

Legal Code Link: http://creativecommons.org/licenses/by-nc/4.0/legalcode

$A B C$ Research Alert uses the CC BY-NC to protect the author's work from misuse.

\section{Abstract}

Tourism is one of the largest growing industries around the world and it has a great role to the GDP in Bangladesh. This paper investigates the core factors that can influence satisfaction level of tourists with specific reference to tourism industry in Bangladesh. Satisfied tourists will revisit the place and they will provide positive word-of-mouth. So it is indispensable to identify which factors around the tour destinations have impact on overall satisfaction of tourists. In carrying out this research, primary data have been collected from 428 tourists of different tourism spots in Sylhet region using structured questionnaire. It is found in the study that the tourists' satisfaction greatly depends on natural beauty, transportation and accommodation facilities, safety and security, and costs. This study reveals that tourist satisfaction depends on a complex process where the role of every actor is fundamental and those actors should be harmonized with each other. Furthermore, this study allows identifying the current strengths and weaknesses of tourism services in Sylhet which may reflect the overall scenario of Bangladesh.

Keywords

Satisfaction, tourism industry, word-of-mouth, tour destinations

\section{Introduction}

Tourism is an emerging industry around the world and thus in Bangladesh. The direct contribution of Travel \& Tourism to GDP was BDT296.6bn (1.9\% of total GDP) in 2014, and is forecast to rise by $5.9 \%$ in 2015 , and to rise by $6.1 \%$ pa, from $2015-2025$, to 
BDT566.3bn (2.0\% of total GDP) in 2025. In 2014 Travel \& Tourism directly supported 903,500 jobs (1.6\% of total employment). This is expected to rise by $2.1 \%$ in 2015 and rise by $1.4 \%$ pa to $1,062,000$ jobs (1.5\% of total employment) in 2025(travel and tourism, Economic Impact, 2015). Bangladesh has a great potential to become one of the market leaders since it has the perfect combination of natural beauty, environment and resources. This study will find out the factors that affect tourism satisfaction. The outcome of the study will detect the problem areas and give direction to improve tourist satisfaction, thus maximizing revenue.

This study is an endeavor of analyzing the factors of tourist satisfaction where we have considered Sylhet division as sample area. Satisfaction has been analyzed by tourism researchers within a variety of dimensions of tourist trips. The main goals of these studies are to identify factors of satisfaction with tourist product-elements, often with the purpose of suggesting tourists' It consists of many aspects, such as deciding with whom to travel, what destination to travel to, where to buy the product, etc. This period includes getting information about these aspects as well. Planning is crucial.

The journey, from leaving home to return, consists of a series of elements, including infrastructural aspects, activity amenities, as well as service elements: transportation, hotel, restaurants, types of activity, number of activities, service level in general, specific activities, the nature/surroundings, travel party, food, etc. After the journey all these elements are viewed as possible influences on overall satisfaction (with the destination) and subsequently on the intention to re-visit and communicate via positive word of mouth. Overall tourist satisfaction with the visited destination is presented as "a state" which is affected by antecedents such as inner motivation for travelling, tourist behavior and satisfaction with trip-related elements.

Tourist satisfaction should be understood by those involved in tourist activities and should serve as a basis for assessing the performance of products and service destination (Noe and Uysal, 1997; Schofield, 2000). Furthermore, an understanding of the different needs of tour groups can help provide appropriate services to enhance their satisfaction at all levels of service. For example, the price factor is not a major factor in shaping the overall satisfaction level for all the tourists. Accommodation and food factors are significant to the entire satisfaction of North America, while the "pull" factor is significant for the European and Asian tourist visitors. Moreover, culture is significant for tourists from Oceania (Hui et al. 2007). Thus service providers such as tour guides should pay attention to the relevant characteristics that might be very important to certain tourist groups managed by them. Based on the existence of such differences, Hui et al. (2007) suggested that Singapore should adopt a balanced approach to satisfy the differing tourists' needs and requirements.

\section{OBJECTIVE OF THE STUDY}

The main objectives of the study are,

1. To identify the factors that affect tourist satisfaction in Sylhet region.

2. To find out the degree of influence of these factors on tourist satisfaction. 
METHODOLOGY OF THE STUDY:

\section{Population and sampling design:}

The data were collected from different tourism spots of Sylhet division from January, 2016 to April, 201. The sample size was 428 and sampling method adopted was a combination of Judgmental and convenience.

\section{Sample characteristics:}

The respondents were chosen irrespective of gender, age, income, education, occupation, religion, location. All the interviewed respondents were tourist in Sylhet.

\section{Instrumentation:}

The instrument used for data collection was a questionnaire developed to identify the factors that affect tourist satisfaction. A five point scale of strongly agree (5), Agree (4), Neutral (3), Disagree (2) strongly disagree (1) were used to measure the responses for the respondents.

\section{Data analysis:}

Collected data were analyzed through factor analysis and regression. Statistical software SPSS-17.0 was used for data analysis.

\section{Reliability:}

Table- 1 shows the reliability of variables, which were used in this research. Cronbach's Alpha describes the internal consistency of the instrument. Here the alpha value is found 0.749 which represents an excellent internal consistency among the variables.

\section{Hypothesis:}

$\mathbf{H}_{\mathbf{O}}$ : There is no significant relationship between the selected factors and the tourists' satisfaction.

$\mathbf{H}_{\mathbf{A}}$ : There is a significant relationship between the selected factors and the tourists' satisfaction.

\section{LITERATURE REVIEW}

Tourism industry is important as it plays an important role in the economy of developing and developed countries. Tourism is a dynamic and competitive industry that requires the ability to adapt constantly to customers' changing needs and desires, as the customer's satisfaction, safety and enjoyment are particularly the focus of tourism businesses. Leading researchers have recognized the important of tourism products: "Misunderstanding of the tourism product is often a constraint in a smoothly functioning tourism system". Tourism product development includes information services, transportations, accommodations, and attraction (Gunn, 2006). The tourism product is described as a series of determinants from variable destinations, which produce an output for tourists. The model consists of a hierarchy of five elements: the physical plant, service, hospitality, freedom of choice, and involvement. As described in this research, the physical plant is the core of the tourism product, which includes the natural resources, fixed properties (such as accommodations), accessibility, acceptable environmental quality, good 
weather, and appropriate numbers of other tourist (Smith, 2000). Tourist satisfaction is a measure of how tourism products and services supplied by a company of the tourism system meet or surpass expectation of tourist. In the tourism context the concept of tourist satisfaction is particularly relevant as well as difficult to deal with as the tourist product is "complex" by definition (Smith, 2000).

Satisfaction is the evaluation of the performance of the overall services provided by the firm received by the customer (Skogland \& Siguaw, 2001). Satisfaction is an important factor to be taken into account by the customer in deciding whether to continue a purchase or otherwise. Satisfaction results when performance exceeds the requirements (Bitner, 1990). On the other hand, when the requirements exceed the performance, dissatisfaction will result (Parasumaran et al. 1990). From a tourism perspective, the same concept applies to tourists because tourists are also subscribers to the services provided. Thus, their decision to visit again also depends on the satisfaction factor. In the discussion of the concept of tourist satisfaction, another term often used is travel satisfaction, which is a result of a tourist's satisfaction after their own experience or the experience of a product or service provided (Gunderson et al., 1996; Heide et al., 1999; Heung, 2000).

Tourist satisfaction can be analyzed as a relationship between the sacrifices and rewards he expects in terms of time, cost or effort and value received (Oliver \& Swan, 1989). Tourists compare their present destination with other alternative or past experience (Yoon \& Usal, 2005). Tourist satisfaction with a particular destination may be the result of multiple factors, including the expectations generated before and during the trip, as well as the tourist's perception of service received. Tourist satisfaction reflects both a cognitive and an emotional phenomenon (Bigne \& Andreu 2004). The analysis of the causes of that generate satisfaction is much scarcer. Among the different types of antecedents that influence tourist satisfaction, a great deal of analysis has been directed towards the attributes of the service offering.

The literature reveals that the level of tourist satisfaction with a particular trip is the result of different factors (Peter \& Olson, 1996) which are generally assessed as a composition between the tourist's perception of products and services he receives and the expectations generated before and during his trip (Barsky \& Labagh 1992; Bigne \& Andreu, 2004; Chon 7 Olsen, 1991). Most studies on tourist satisfaction focus on measurement techniques and types of variables related to customer satisfaction (Noe and Uysal 1997; Zeithaml, Berry and Parasuraman 1993). Tourist satisfaction is defined as post-consumption evaluation concerning a specific product or service (Westbrook \& Oliver, 1991), and proposed to be one of the key judgments that tourists make regarding a tourism service. Hence, it is a well-established, long-standing focus marketer attention (Yuksel \& Yuksel, 2002).

Tourist satisfaction is important to successful destination marketing because it influences the choice of destination, the consumption of products and services, and the decision to return (Kozak \& Rimmington, 2000). Pearce (2008) defined tourism entertainment as structured and managed situations designed for a predominantly visitor audience, which include cultural shows, dance performances, theme park presentations, fun guided tours, and film and video presentations tailored exclusively for visitors. Choosing a holiday destination is a rational process involving different factors (McGehee, Loker-Murphy \& Uysal): the tourist feels the need to travel and looks for a "product" which initially may offer the greatest satisfaction to 
fulfill that need. In such a process, the tourist feels 'pushed' by internal and emotional factors, as well as attracted by the characteristics of the destination and the availability of activities (Crompon, 1979; Dann, 1977; Uysal \& Jurowski, 1994). The distinction between overall satisfaction and attribute satisfaction is discussed as important, given that overall satisfaction is based on the overall experience, not just a single feature of the product (Spreng, Mackenzie \& Olashavsky 1996). Tourists`satisfaction with a destination may reflect a type of tourist overall satisfaction with a journey, while satisfaction with transport, travelling party, accommodation, activities performed while staying at the destination, etc., could impact upon the total judgment of a trip to a particular destination. Many reasons cause tourists to be satisfied with their trip or journey, including the quality of the services provided, such as infrastructure, security, cleanliness, natural situation, consumer protection and easily obtained (Handszuh, 1995). According to Cornin \& Taylor (1992), and Ekinci \& Riley (1998) quality of service is part of the process which leads to the formation of the overall satisfaction. With reference to the tourism sector, a review of the literature on motivation reveals that people travel because they are "pushed" into making travel decisions by internal, psychological forces, and "pulled" by the external forces of the destination attributes (Crompton, 1979; Dann, 1977; Uysal and Jurowski, 1994). Ross and Iso-Ahola (1991), for instance, study satisfaction with cultural tours, while Hsieh, O'Leary and Morrison (1994) study differences among packaged and non-packaged tours. Other researchers focus on satisfaction with certain aspects of a tour, e.g. hotels (Saleh and Ryan 1992; Heide, Grønhaug \& Engset 1999). Tourists' shopping satisfaction is studied by Reisinger and Turner (2002). In addition, physical factors, such as the destination product performance and psychological equipment products, such as meaningful destination are also factors that translate to satisfaction and loyalty of travel destination (Uysal \& Noe, 2003). Chi \& Qu (2008) chose 33 destination items to measure tourist satisfaction, and distinguished seven key factors: lodging, dining, shopping, attractions, activities and events, environment, and accessibility. According to some authors (Kozak \& Rimmington, 1999) some attributes can contribute to the real destination competitiveness. These attributes refer to the variables that influence the satisfaction or dissatisfaction of tourists during their vacation.

The three most important satisfaction attributes relating to intention to re-visit are the level of overall satisfaction, satisfaction with destination airport services and satisfaction with local transport services, respectively. Kozak (2003) measures tourist satisfaction with multiple destination attributes and subsequent intention to repeat visitation and recommend to others among four different groups of tourists visiting two different destinations (Cherry \& Ordenez, 2003). The selection of tourist's decisions and behaviors depend on three stages such as before the journey, tourist experience at the destination and tourist experience at the spot. A highly competitive market, being able to offer an attractive tourist destination implies having a deep understanding of the motives that lead tourist to make their choice among the different alternative available, as well as of the degree of satisfaction obtained with the services provided (Jang \& Feng, 2007).

One of the most relevant research issues for the tourist sector is to analyze why people travel and what they expect from their destination (Yoon \& Uysal, 2005), i.e.; what are the motive behind the trip. Consumer behavior literature states that need and motivation are interrelated (Witt \& Wright, 2006). A series of research has tried to classify the main attributes of any particular destination (Kale \& Weir, 1986). Such items include climate, culture, architecture, 
transport, entertainment or cost. Danahar and Arweiler (1996) established that, although the experience associated with items relating to transport and accommodation affects the degree of tourist satisfaction, positive tourist feedback focused mainly on outdoor activities. The results of the Kozak (2003) study show that overall tourist satisfaction, the intention to recommend and the intention to repeat visit, are affected by multiple attributes and differ from one customer group- and from one destination to another. This implies further empirical testing of tourists with different nationalities visiting a variety of destinations.

Satisfied tourists tend to communicate their positive experience to others (word of mouth) and they tend to buy the product repeatedly (re-buy) (e.g. Barsky 1992; Beeho and Prentice 1997; Hallowell 1996; Kozak \& Rimmington 2000; Pizam 1994; Ross 1993).

According to (Truong and D. Foster 2006) positive attributes refers to characteristics conveying favorable impressions about the destination, whereas negative attributes are those doing the opposite. As (Yoon \& M. Uysal, 2005) both positive as well as negative destination attributes are important in evaluating the holiday experiences. Moreover, (Tribe \& Snaith, 1998) pointed out that the negative attributes can provide unfavorable effects on holiday satisfaction.

\section{DATA ANALYSIS AND FINDINGS}

From the literature review and personal observation researchers found out fifteen variables which may significantly influence the tourists' satisfaction. Fifteen statements were designed on variables found from literature review. Factor analysis was conducted on those 15 variables.

\section{Demographic profile:}

Data was collected from 428 tourists from different tour destinations in Sylhet region. During collecting responses of tourists regarding tour satisfaction their demographic details also collected. The demographic description of the respondents is presented in table- 2 .

\section{Factor analysis:}

To find out the key factors influence the tourists' satisfaction factor analysis has been performed. Principal Component Analysis (PCA) is a commonly used method for grouping the variables under few unrelated factors. Variables with a factor loading of higher than 0.5 are grouped under a factor. A factor loading is the correlation between the original variable with the specific factor and the key to understanding the nature of that particular factor (Debasish 2004).

For conducting factor analysis confirming sampling adequacy is necessary. There are a few methods to detect sampling adequacy. From the table -3 it is observed that KMO is 0.708 that is more than the required value of 0.50 . It indicates that there is no error in $70.8 \%$ of the sample and in remaining $29.2 \%$, there may be some sort of error. So it can be conclude that the present sample is adequate for conducting factor analysis (Barkus, Yavorsky, \& Foster, 2006; Leech, Barrett, \& Morgan, 2005). Table-3 also present the result of Bartlett's test of sphere city. Bartlett's test of sphere city indicates the strength of relationship among the variables. We may assume the following hypothesis: 
$\mathrm{H}_{0}$ : There is no significant correlation among the factors affecting tourist satisfaction.

$\mathrm{H}_{1}$ : There is significant correlation among the factors affecting tourist satisfaction.

The value of Chi-square test (1015.947 with significance level 0.000) signifies the rejection of null hypothesis. It means that the population correlation matrix is not an identity matrix. There is significant correlation among the factors that affect tourist satisfaction.

Since the Kaiser-Meyer-Olkin Measure of Sampling Adequacy and Bartlett's Test of Sphericity confirm factorability, researchers proceed for factor analysis.

The summery of the factor analysis has been presented in table-4. By performing factor analysis among 15 variables 5 factors were categorized. The first factor, i.e. transportation and safety has an eigen value of 3.359. Since this is greater than 1.0, it explains more variance than a single variable, in fact 3.359 times as much. This factor explains $22.392 \%$ of total variance. The Cronbach's alpha value is 0.779 which represent a good the internal consistency of data within the factor. The second factor extracted is natural and environmental beauty. The eigen value of this factor is 1.670. This factor is accounted for $11.137 \%$ of the total variance. The Cronbach's alpha value 0.5524 represents passable internal consistency of data. The third factor that affects the tourist satisfaction is accommodation facility. This factor is accounted for $9.401 \%$ of the total variance. The alpha value 0.6748 represents a good internal consistency. The fourth factor extracted is food and local inhabitant's behavior which is accounted for a handsome figure of variance (7.657). The last factor that affects tourist satisfaction is cost of accommodation which explains $7.154 \%$ of the total variance. All of these five factors are accounted for $57.740 \%$ of the total variance.

\section{Regression analysis:}

Regression analysis is a powerful and flexible method for analyzing associative relationship between dependent variable and independent variable. Here the regression analysis is done to determine how much of the variation in tourist satisfaction can be explained by five extracted factors.

Table-5 represents the modes summery of regression analysis. In this table $\mathrm{R}$ is the multiple correlations co-efficient, its value is $0.752 . R^{2}$ is a statistical measure of how close the data are to the fitted regression line. It is also known as the coefficient of determination, or the coefficient of multiple determinations for multiple regressions. The value of $\mathrm{R}^{2}$ is 0.565 , which means that $56.5 \%$ of the total variance in tourist satisfaction has been 'explained' by predictor variables.

The $F$-ratio in the ANOVA table (table-6) tests whether the overall regression model is a good fit for the data. The table shows that the independent variables statistically significantly predict the dependent variable, $F(5,369)=24.836, p<.0005$ (i.e., the regression model is a good fit of the data).

Unstandardized coefficients indicate how much the dependent variable varies with an independent variable when all other independent variables are held constant. From table-7 considering overall satisfaction as dependent variable and Cost of accommodation, Foods and Inhabitants' behavior, Accommodation facility, Natural environment and beauty, Transportation and safety as independent variable following regression equation may be developed: 
$\mathrm{Y}=4.091+0.204$ (Transportation and safety) +0.151 (Natural environment and beauty) +0.128 (Accommodation facility) +0.157 (Foods and Inhabitants' behavior)-0.041(Cost of accommodation) +error term

Here, $\mathrm{Y}=$ Tourist satisfaction level in Sylhet region

\section{CONCLUSION}

Tourism can provide an immense contribution to the economy of Bangladesh. It shapes the socio-cultural and economic condition of local inhabitants. So it is worthy to know which factors affect tourist satisfaction. This study identified the factors which may influence the tourist satisfaction. The findings of this study can be used by the tour operators, government tourism authorities and other concerned parties in their strategy formulation.

This study focuses only on the intangible and tangible factors of tourism destination. However, further researches can be conducted to measure the influence of psychographic variables on tourist satisfaction.

\section{References}

Annals of Tourism Research, Vol.18 (2), pp.226-237

Annals of Tourism Research. Vol. 20: 477-489.

B. Cherry, L., D. Ordóñez, \& S. W. Gilliland. (2003). Grade Expectations: the Effects of Expectations on Fairness and Satisfaction Perceptions. Journal of Behavioral Decision Making, 16, 375-395.

Barkus, E., Yavorsky, C., \& Foster, J. (2006). Understanding and using advanced statistics. Faculty of Health \& Behavioural Sciences-Papers, 393.

Barsky, J. D. (1992). Customer Satisfaction in the Hotel Industry: Meaning and Measurement. Hospitality Research Journal, 16 (1), 51-73.

Beeho, A.J. \& R.C. Prentice (1997). Conceptua lizing the experiences of heritage tourists: a case study of new lanark world heritage village. Tourism Management, 18(2), 75-87.

Bigné, J.E., \& Andreu, L. (2004). Modelo Cognitivo-Afectivo De La Satisfacción En Servicios De Ocio Y Turismo. Cuadernos de Economíay Dirección de la Empresa, 21, 89-120.

Bitner, M. J. (1990). Evaluating service encounters: the effects of physical surroundings and employee responses. Journal of Marketing, 54, 69-82.

C.A. Gunn. (2004). Tourism Planning, 2nd Edition, New York, Taylor and Francis

Chi C, \& Qu H. (2008). Examining the structural relationships of destination image, tourist satisfaction and destination loyalty: an integrated approach. Tourism Management, 29(4), 624-636.

Crompon D, \& Dann, G. (1977). Anomie, ego-enhancement and tourism. Annals of Tourism Research, 4 (2), 184-194.

Cronin, J. J. \& Taylor, S. A., (1992). Measuring service quality: a reexamination and extension. Journal of Marketing, 65, 55-68.

Cropmton, J. L. (1979). Motivation for pleasure vacation, Annals of Tourism Research, 6, 408-424.

Danaher, P.J. \& N. Arweiler. (1996). Customer satisfaction in the tourist industry: a case study of visitors to new zealand. Journal of Travel Research, 34, 89-93.

Debasish S. S. (2004). Exploring customer preference for life insurance in india-factor analysis method, Vilakshan. 1(1).

Ekinci, Y. \& Riley, M. (1998). A critique of the issues and theoretical assumptions in service quality measurement in the lodging industry: time to move the goal-posts? International Journal of Hospitality Management, $17,349-362$

Gundersen, M.G., Heide, M. \& Dan Olsson, U.H. (1996). Hotel guest satisfaction among business travelers what are the important factors? Cornell hotel and restaurant administration quarterly, 36 (2), 72-81

Handszuh, H. F. (1995). Developing quality in tourism services: a brief review. In Richards, G., Tourism in Central and Eastern Europe: Educating For Quality. The Netherlands: Tilburg University Press, 225-240

Heide, M., Gronhaug, K. \& Engset ,M.G. (2001) Industry specific measurement of consumer satisfaction: experiences from the business travelling industry. International Journal of Hospitality Management, 18, 201-213. 
Hsieh, S., O`Leary, J.T. \& Morrison,A.M.(1996). A comparison of packaged and non packaged travelers from the United Kingdom. Global Toruist Behaviour. Ed. M. Uysal. New York: International Business Press, 79-100

Hui, T.K., Wan, D. \& Ho, A. (2007). Tourists' satisfaction, recommendation and revisiting Singapore. Tourism Management, 28 (4), 965-975.

J. Tribe \& T. Snaith. (1998). From SERVQUAL to HOLSAT: Holiday Satisfaction in Varadero, Cuba, Tourism Management, 19, 25-34.

Janf, S., \& Feng, R. (2007). Temporal destination revisit intention: the effects of novelty seeking and satisfaction. Tourism Management, 28, 580-590.

Jang, S.C., A.M. Morrison \& J.T.O'Leary. (2002). Benefit segmentation of japanese pleasure travelers to the USA and canada selecting target markets based on the profitability and risk of individual market segments. Tourism Management, 23, 367-378

Kale, S.H., \& Weire, K.m. (1989). Marketing third world countries to the western travelers. Annals if Tourism Research, 25(2), 2-7.

Kearney, A. T. (2002). Regional benchmarking of malaysia's competitiveness and synergies partnership with China and ASEAN Countries. Majlis Tindakan Ekonomi Negara.

Kozark, M., \& Rimmington, M. (2000). Tourist satisfaction with mallorca, spain, as an off-season holiday destination. Journal of Travel Research, 38, 260-269

Leech, N. L., Barrett, K. C., \& Morgan, G. A. (2005). SPSS for Intermediate Statistics: Use and Interpretation. Psychology Press.

McGhehee, N.G., Loker-Murphy, L., \& Uysal, M. (1996). The australian international pleasure travel market; motivational travel flows. Journal of Tourism studies, 7(1), 45-57.

Noe, F.P., \& Uysal, M. (1997). Evaluation of outdoor recreational settings. A problem of measuring user satisfaction. Journal of Retailing and Consumer Services, 4 (4), 223-230.

Oliver R. L. (1991). The dimensionality of consumption emotion patterns and consumer satisfaction. Journal of Consumer Research, 18(1), 84-91.

Oliver, R. L. \& J. E. Swan. (1989). consumer perceptions of interpersonal equity and satisfaction in transactions: a field survey approach. Journal of Marketing, 53, 21-35.

Parasuraman, A., Zeithaml, V. \& Berry, L. (1990). Delivering Quality Service. New York, Free Press.

Pearce PL. (2008). Tourism and entertainment: boundaries and connections. Tourism Recreation Research, 33(2), 125-130.

Pearce, D. (2008). Tourist time-budgets. Annuals of Tourism Research, 15(1), 106-121.

Peter, J. P., \& Olsen, J.C. (1996). Consumer Behavior and Marketing strategy, Chicago, Irwin.

Pizam, A. (1994). Monitoring Customer Satisfaction. In Food and Beverage Management: A Selection of Readings . Eds. B David and A. Lockwood. Oxford, UK: Butterworth-Heinemann, pp. 231-2

Reisinger, Y., \& L.W. Turner (2002). The determination of shopping satisfaction of japanese tourists visiting Hawaii and the Gold Coast Compared. Journal of Travel Research, 41(November), 167-176,

Ross, E.L.D. \& Iso-Ahola, S. E. (1991).sightseeing tourists' motivation and satisfaction. Annals of Tourism Research, 18 (2), 226-237.

Ross, G. (1993). destination evaluation and vacation preferences. Annals of Tourism Research, 20, 477-489.

Saleh, F., \& Ryan, C. (1991). Analyzing service quality in the hospitality industry using the SERVQUAL model. The Service Industries Journal, 11(3): 324-343.

Smith, S. L. J. (2000). The Tourism Product, Annals of Tourism research. Retrieved from: http://ftur.uh.cu/in

Spreng, R. A. S., R.W. Mackenzie \& R.W. Olashavsky. (1996). A reexamination of the determinants of consumer satisfaction. Journal of Marketing. 60, 15-32.

T. Truong \& D. Foster. (2006). Using HOLSAT to evaluate tourist satisfaction at destination: the case of australian holidaymakers in Vietnam. Tourism Management, 842-855,

Travel and Tourism, Economic Impact Bangladesh (2015), The Authority On World Travel And Tourism.

Uysal, M. \& Noe, F. (2003). Satisfaction in outdoor recreation and tourism settings. In E. Laws (Ed.), Case Studies in Tourism Marketing. London, Continuum Publisher, 140-158.

Witt, C. A., \& Wright, P. L. (1992). Tourism motivation: life after Maslow. In, Peter Johnson and Barry Thomas ( eds ), Choice and Demand in Tourism, London, Mansell.

Y. Yoon \& M. Uysal. (2005). An examination of the effects of motivation and satisfaction on destination loyalty: A structural model. Tourism Management, 26, 45-56.

Yuksel, A., \& Yuksel, F. (2002). Measurement of tourist satisfaction with restaurant services: a segment-based approach. Journal of Vacation Marketing, 9(1), 52-68. 


\section{APPENDICES}

Table-1: Reliability Statistics

\begin{tabular}{|c|c|}
\hline Cronbach's Alpha & N of Items \\
\hline 0.749 & 16 \\
\hline
\end{tabular}

Table-2: Demographic description of the respondents

\begin{tabular}{|c|c|c|c|c|}
\hline & & Frequency & Percent & Cumulative Percent \\
\hline \multirow[t]{3}{*}{ Gender } & Male & 276 & 64.5 & 64.5 \\
\hline & Female & 152 & 35.5 & 100.0 \\
\hline & Total & 428 & 100.0 & \\
\hline \multirow{8}{*}{ Age } & & & & \\
\hline & $15-20$ years & 45 & 10.5 & 10.5 \\
\hline & $21-25$ years & 177 & 41.4 & 51.9 \\
\hline & 26-30 years & 83 & 19.4 & 71.3 \\
\hline & $30-35$ years & 69 & 16.1 & 87.4 \\
\hline & $36-40$ years & 27 & 6.3 & 93.7 \\
\hline & Above 40 years & 27 & 6.3 & 100.0 \\
\hline & Total & 428 & 100.0 & \\
\hline \multirow[t]{3}{*}{ Marital status } & Single & 246 & 57.5 & 57.5 \\
\hline & Married & 182 & 42.5 & 100.0 \\
\hline & Total & 428 & 100.0 & \\
\hline \multirow{6}{*}{ Education level } & SSC & 30 & 7.0 & 7.0 \\
\hline & HSC & 99 & 23.1 & 30.1 \\
\hline & Honors & 170 & 39.7 & 69.9 \\
\hline & Masters & 74 & 17.3 & 87.1 \\
\hline & Others & 55 & 12.9 & 100.0 \\
\hline & Total & 428 & 100.0 & \\
\hline \multirow[t]{6}{*}{ Occupation } & Business & 71 & 16.6 & 16.6 \\
\hline & Service & 93 & 21.7 & 38.3 \\
\hline & Student & 183 & 42.8 & 81.1 \\
\hline & House wife & 43 & 10.0 & 91.1 \\
\hline & Others & 38 & 8.9 & 100.0 \\
\hline & Total & 428 & 100.0 & \\
\hline \multirow{9}{*}{$\begin{array}{l}\text { Monthly family } \\
\text { income }\end{array}$} & less than tk. 10000 & 81 & 18.9 & 19.2 \\
\hline & above tk. $10000-20000$ & 68 & 15.9 & 35.4 \\
\hline & above tk. $20000-30000$ & 98 & 22.9 & 58.7 \\
\hline & above tk. $30000-40000$ & 67 & 15.7 & 74.6 \\
\hline & above tk. $40000-50000$ & 49 & 11.4 & 86.2 \\
\hline & above tk. 50000 & 58 & 13.6 & 100.0 \\
\hline & Total & 421 & 98.4 & \\
\hline & Missing & 7 & 1.6 & \\
\hline & Total & 428 & 100.0 & \\
\hline
\end{tabular}

Table-3: KMO and Bartlett's Test

\begin{tabular}{|l|l|c|}
\hline \multicolumn{2}{|l|}{ Kaiser-Meyer-Olkin Measure of Sampling Adequacy. } & .708 \\
\hline Bartlett's Test of Sphericity & Approx. Chi-Square & 1015.947 \\
\cline { 2 - 3 } & df & 105 \\
\cline { 2 - 3 } & Sig. & .000 \\
\hline
\end{tabular}


Table-4: Rotated Component Matrix

\begin{tabular}{|c|c|c|c|c|c|}
\hline & 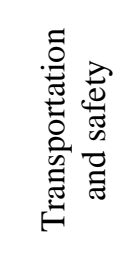 & 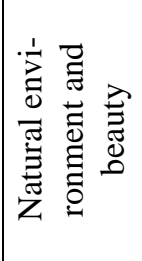 & 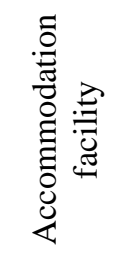 & 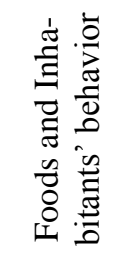 & 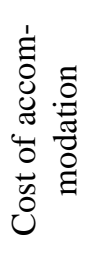 \\
\hline Transportation system & 0.708 & & & & \\
\hline Condition of roads & 0.706 & & & & \\
\hline Personal safety and security & 0.684 & & & & \\
\hline Washroom/toilet/changing room & 0.565 & & & & \\
\hline Information adequacy & 0.510 & & & & \\
\hline Relaxing environment & & 0.724 & & & \\
\hline Natural beauty & & 0.669 & & & \\
\hline Air quality & & 0.551 & & & \\
\hline Historical and religious places & & 0.454 & & & \\
\hline Condition of rooms and other facilities of hotel & & & 0.828 & & \\
\hline Services in hotels & & & 0.775 & & \\
\hline Behavior and cordiality of local people & & & & 0.663 & \\
\hline Quality of foods and beverages & & & & 0.661 & \\
\hline Price of foods and beverages & & & & 0.639 & \\
\hline Cost of accommodations/hotels & & & & & 0.767 \\
\hline Initial Eigenvalues & 3.359 & 1.670 & 1.410 & 1.149 & 1.073 \\
\hline$\%$ of Variance & 22.392 & 11.137 & 9.401 & 7.657 & 7.154 \\
\hline Reliability & 0.779 & 0.5524 & 0.6748 & 0.5089 & \\
\hline
\end{tabular}

Table -5:Model Summary

\begin{tabular}{|c|c|c|c|c|}
\hline Model & $\mathrm{R}$ & R Square & $\begin{array}{c}\text { Adjusted R } \\
\text { Square }\end{array}$ & $\begin{array}{c}\text { Std. Error of the } \\
\text { Estimate }\end{array}$ \\
\hline 1 & $0.752 \mathrm{a}$ & 0.565 & 0.555 & 0.36765 \\
\hline
\end{tabular}

a. Predictors: (Constant), Cost of accommodation, Foods and Inhabitants' behavior, Accommodation facility, Natural environment and beauty, Transportation and safety

Table-6: ANOVA

\begin{tabular}{|l|l|c|c|c|c|c|}
\hline \multicolumn{2}{|c|}{ Model } & Sum of Squares & df & Mean Square & F & Sig. \\
\hline \multirow{3}{*}{1} & Regression & 40.014 & 5 & 8.003 & \multirow{2}{*}{24.836} & \multirow{2}{*}{$0.000 \mathrm{a}$} \\
\cline { 2 - 5 } & Residual & 118.903 & 369 & 0.322 & & \\
\cline { 2 - 5 } & Total & 158.917 & 374 & & & \\
\hline
\end{tabular}

a. Predictors: (Constant), Cost of accommodation, Foods and Inhabitants' behavior, Accommodation facility, Natural environment and beauty, Transportation and safety 
Table-6: ANOVA

\begin{tabular}{|l|l|c|c|c|c|c|}
\hline \multicolumn{2}{|c|}{ Model } & Sum of Squares & df & Mean Square & F & Sig. \\
\hline \multirow{4}{*}{1} & Regression & 40.014 & 5 & 8.003 & \multirow{2}{*}{24.836} & $0.000 \mathrm{a}$ \\
\cline { 2 - 5 } & Residual & 118.903 & 369 & 0.322 & & \\
\cline { 2 - 5 } & Total & 158.917 & 374 & & & \\
\hline
\end{tabular}

a. Predictors: (Constant), Cost of accommodation, Foods and Inhabitants' behavior, Accommodation facility, Natural environment and beauty, Transportation and safety

b. Dependent Variable: Your overall satisfaction regarding Sylhet.

Table-7: Coefficients

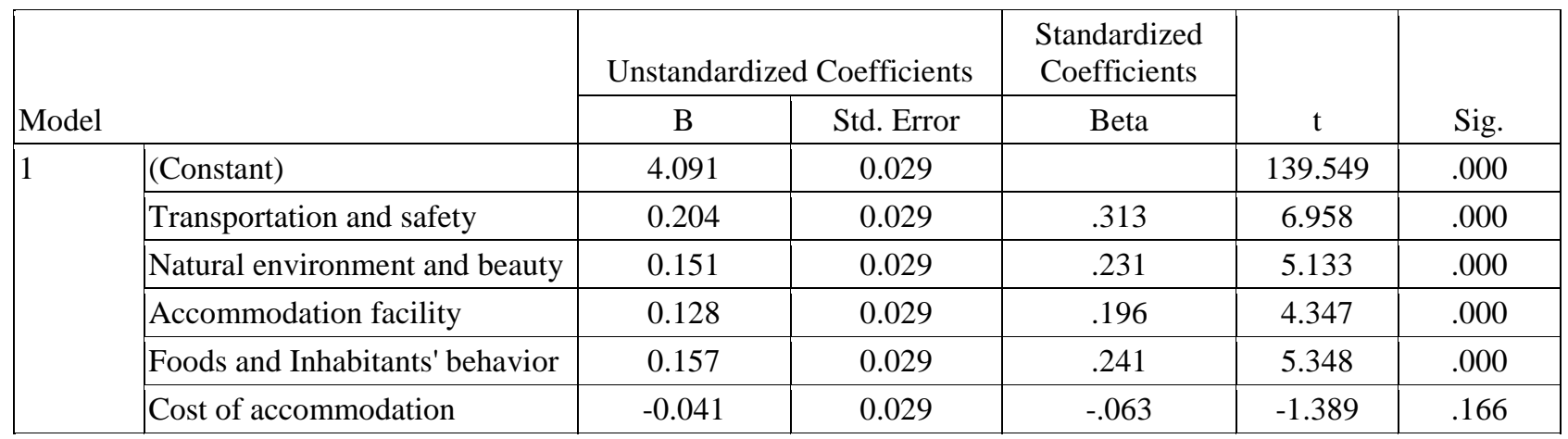

a. Dependent Variable: Your overall satisfaction regarding Sylhet. 